\title{
Effect of Prematurity, Birthweight, Maternal Stress, Socio-economic Status, and Mother-Child Intimacy on the Development of Preschool Children in Surakarta
}

\author{
Silfia Angela N Halu'), Bhisma Murti'), Didik Tamtomo²) \\ 1)Masters Program in Public Health, Sebelas Maret University \\ ${ }^{2)}$ Department of Anatomy, Faculty of Medicine, Sebelas Maret University
}

\begin{abstract}
Background: Monitoring child development is an important step to prepare healthy children from the earliest age, both physically, spiritually, and socially. Monitoring child development can be done in the kindergarten. Some kindergartens in Surakarta, however, have not implemented child development monitoring program. This study aims to determine the effect of prematurity, birthweight, maternal stress, socio-economic status, and mother-child intimacy, on the development of preschool children.

Subjects and Method: This was an analytical observational study using case control design. The study was carried out at 7 kindergartens (TK) in Surakarta, Central Java: TK Negeri Pembina, TK Gaya Baru III, TK Kristen Ngasinan, TK Islam Bakti 6, TK Advent, TK Warga and TK Kanisius Imakulata, from May to June 2017. A sample of 120 children aged 5-6 years old attending kindergartens were selected for this study by fixed exposure sampling, i.e. selection based on prematurity status. The dependent variable was child development. The independent variables were prematurity, birthweight, maternal stress, maternal employment status, maternal education, family income, parenting time, and mother-child intimacy. The data were collected by a set of pretested questionnaire. Child development was measured by development pre-screening questionnaire (KPSP). Nutritional status was obtained from maternal and child health recording book. Path analysis was employed for data analysis.

Results: Child development was directly affected by prematurity $(b=0.29 ; \mathrm{SE}=0.07 ; \mathrm{p}<0.001)$, birthweight $(b=0.04 ; \mathrm{SE}=0.18 ; p=0.007)$, maternal employment $(b=0.46 ; \mathrm{SE}=0.20 ; \mathrm{p}=0.020)$, maternal education $(b=0.65 ; \mathrm{SE}=0.21 ; \mathrm{p}=0.002)$, family income $(b=0.01 ; \mathrm{SE}=0.01 ; \mathrm{p}=0.015)$, and mother-child intimacy $(\mathrm{b}=0.26 ; \mathrm{SE}=0.05 ; \mathrm{p}<0.001)$. Family income was affected by maternal employment $(b=23.37 ; \mathrm{SE}=5.52 ; \mathrm{p}<0.001)$ and maternal education $(b=23.50 ; \mathrm{SE}=5.79 ; \mathrm{p}<0.001)$. Mother-child intimacy was affected by maternal stress $(b=0.01 ; \mathrm{SE}=0.01 ; \mathrm{p}=0.052)$ and parenting time $(b=0.56 ; \mathrm{SE}=0.05 ; \mathrm{p}<0.001)$.
\end{abstract}

Conclusions: Child development is directly affected by prematurity, birthweight, maternal employment, maternal education, family income, and mother-child intimacy.

Keywords: child development, prematurity, birthweight, socio-economic status, maternal stress, mother-child intimacy

\section{Correspondence:}

Silfia Angela N Halu. s Program in Public Health, Sebelas Maret University, Surakarta. Email: occe.halu@gmail.com. Mobile: +6285338395484.

\section{LATAR BELAKANG}

Anak prasekolah adalah anak yang termasuk dalam kelompok umur 5 tahun (6o bulan) sampai 6 tahun (72 bulan).Anak dilingkungan prasekolah wajib dilakukan pemantauan dalam proses perkembangannya
(Kemenkes RI, 2014). Pencapaian perkembangan seorang anak tidak dapat dipisahkan dari beberapa domain, yaitu perkembangan kognitif, perkembangan motorik kasar dan motorik halus, perkembangan sosial emosional dan perkembangan bahasa 
Journal of Maternal and Child Health (2017), 2(3): 187-199

https://doi.org/10.26911/thejmch.2017.02.03.01

(Bartolatta dan Shulman, 2014). Proses perkembangan pada anak dipengaruhi oleh beberapa faktor salah satunya adalah faktor lingkungan postnatal berupa kondisi anak pada saat lahir, status sosial ekonomi (Hidayat, 2008) dan interaksi anak dengan orangtua, teman sebaya dan guru (Daniel dan Gilligan, 2010).

Kelahiran prematur merupakan permasalahan kesehatan yang terjadi pada saat bayi dilahirkan. Anak yang dilahirkan prematur akan mengalami gangguan proses penting pada perkembangan otaknya yang berakibat pada timbulnya berbagai masalah tumbuh kembang berkaitan dengan kesehatan, penyesuaian psikologis dan fungsi intelektual (Joyce et al., 2012).

Berat badan lahir juga merupakan faktor postnatal yang berpengaruh terhadap perkembangan anak dikemudian hari. Perkembangan anak dengan riwayat berat badan lahir normal atau lebih maupun berat badan lahir rendah memiliki perbedaan yang mendasar (Gill et al., 2013). Anak yang dilahirkan dengan berat badan lahir rendah akanmengalamiresiko peningkatan terjadinya berbagai penyakit seperti kanker, penyakit ginjal, gangguan pendengaran, depresi, penyakit jantung yang berakibat pada terganggunya perkembangan dan berdampak pada pencapaian akademik (Negrato dan Gomes, 2013).

Kesehatan orangtua maupun pengasuh merupakan salah faktor yang mempengaruhi perkembangan anak prasekolah (Spittle et al., 2016). Orangtua terutama ibu sangat berperan dalam tahap perkembangan anak (Depkes RI, 2014). Anak yang terlambat atau terganggu proses perkembangannya akan meninkatkan stres pada ibu (Estes et al., 2009). Kondisi ibu yang depresi berhubungan erat dengan kemampuan sosial anak prasekolah dalam melaksanakan kegiatan di lingkungan sekolah (Silvestein et al., 2010).
Faktor sosioekonomi seperti pekejaan orangtua mengambil peran penting dalam perkembangan anak. Orangtua yang memiliki pekerjaan yang layak akan mendapatkanpenghasilanyang tinggi sehingga orangtua mampu untuk memenuhi segala kebutuhan anak dalam periode emas perkembangannya. Ibu yang juga bekerja akan menambah penghasilan keluarga untuk menunjang kesejahteraan anggota keluarga (Hsin dan Felfe, 2014).

Pendapatan keluarga juga merupakan faktor resiko yang berdampak pada tahap perkembangan anak. Anak yang lahir dari keluarga dengan berpenghasilan rendah akan berdampak besar dalam melakukan perilaku menyimpang dibanding anak yang lahir dari keluarga berpenghasilan besar atau berkecukupan (Cooper et al., 2009). Anak yang berasal dari keluarga kurang beruntung akan mengalami keterlambatan dalam perkembangan kognitif, bahasa, sosial dan perkembangan motorik (Kim et al, 2012). Anak yang berasal dari keluarga kurang beruntung akan mengalami keterlambatan dalam perkembangan kognitif, bahasa, sosial dan perkembangan motorik (Kim et al., 2012).

Pendidikanmerupakan proses pembelajaran yang dilakukan oleh peserta didik untuk mengembangkan serta meningkatkan potensi yang ada dalam dirinya(Republik Indonesia, 2003). Ibu merupakan faktor penentu yang paling penting dan utama dalam kesehatan anak termasuk dalam tahap perkembangannya Chen dan $\mathrm{Li}$ (2009).

Keluarga terutama ibu merupakan kunci utama dalam tahap tumbuh kembang anak. Baik atau buruknya moral anak dalam bersosialisasi dengan lingkungan sekitar dipengaruhi oleh terjalinnya hubungan yang kuat di antara ibu dan anak. Hubungan yang terbentuk antara ibu dan anak dapat di ketahui melalui waktu yang diha- 
biskan bersama. Waktu asuh yang dimiliki oleh ibu sangat berperan penting dalam perkembangan anak fisik, emosi dan sosial anak (Depkes RI, 2014). Anak yang dibesarkan dengan kekurangan kasih sayang akan mengalami hambatan maupun gangguan pada proses perkembangannya baik di masa saat ini maupun berdampak besar di masa mendatang (Depkes RI, 2013). Ibu diharapkan dapat terus mendampingi pertumbuhan dan perkembangan anak agar dapat memantau serta mendeteksi apabila terjadi penyimpangan pada anak (Noordiati et al., 2015).

Berdasarkan uraian diatas peneliti memiliki ketertarikan untuk meneliti pengaruh premarutitas, berat badan lahir, tingkat stres ibu, status sosioekonomi dan kedekatan ibu anak terhadap perkembangan anak prasekolah di kota Surakarta.

\section{Desain Penelitian}

Metode penelitian pada penelitian ini adalah studi analitik observasional, dengan pendekatan desain cross sectional. Penelitian di laksanakan di TK Negeri Pembina, TK Gaya Baru III, TK Kristen Ngasinan, TK Islam Bakti 6, TK Advent, TK Warga dan TK Kanisius Immakulata. Waktu pelaksanaan mulai bulan Mei-Juni 2017 di di Taman Kanak-Kanak di Kota Surakarta.

\section{Populasi dan Sampel}

Populasi penelitian ini adalah seluruhanak prasekolah di Kota Surakarta. Sampel dari penelitian ini adalah anak prasekolah berusia 5-6 tahun dengan berjumlah 120, berdomisili di Kota Surakarta serta terpilih sebagai subjek sesuai dengan kriteria inklusi. Kriteria inklusi penelitian ini adalah anak prasekolah berusia 5-6 tahun dan ibu serta anak prasekolah hadir saat penelitian berlangsung. Teknik sampling yang digunakan dalam penelitian ini adalah purposive samplingdengan skema pencuplikan menggunakan fixed exsposure sampling.

\section{Variabel Penelitian}

Terdapat delapan variabel dalam penelitian yang terbagi menjadi variabel dependen dan variabel dependen. Variabel dependen yaitu perkembangan anak dan variabel independen yaitu prematuritas, berat badan lahir, tingkat stres ibu,status sosioekonomi dan kedekatan ibu anak.

\section{Definisi Operasional}

Definisi operasional dari perkembangan adalah bertambahnya struktur fungsi tubuh yang lebih kompleks dalam kemampuan gerak kasar, gerak halus, bicara dan bahasa serta sosialisasi dan kemandirian. Prematuritas adalah bayi yang dilahirkan sebelum waktu perkembangan selesai dan hanya mencapai usia kehamilan kurang dari 37 minggu. Berat badan lahir adalah berat badan seorang bayi yang ditimbang dalam kurun waktu 1 jam setelah dilahirkan dengan menggunakan satuan gram.

Tingkat stres ibu adalah situasi yang penuh dengan tekanan yang terjadi pada orangtua terutama ibu dalam melaksanakan pengasuhan pada anak. Pekerjaan adalah suatu kegiatan atau aktivitas yang melibatkan pekerja dan penyedia pekerjaan yang nantinya pekerja akan mendapatkan upah sesuai dengan apa yang ia kerjakan. Pendapatan keluarga adalah pendapatan yang dihasilkan oleh anggota keluarga baik bapak dan ibu hasil dari pekerjaan yang dilakukan. Pendidikan ibu adalah upaya yang dilakukan ibu dalam menempuh pendidikan formal untuk mengubah dan meningkatkan pengetahuan yang dimiliki untuk menunjang kualitas hidup yang lebih baik demi keluarga dan pertumbuhan dan perkembangan anak.

Waktu asuh adalah waktu yang dijalani ibu dalam perannya sebagai seorang ibu dalam memberikan perhatian yang memadai dan menghabiskan waktu untuk 
Journal of Maternal and Child Health (2017), 2(3): 187-199

https://doi.org/10.26911/thejmch.2017.02.03.01

mengasuh anak. Kedekatan ibu anak adalah Interaksi yang terjalin antara ibu dan anak dengan melakukan aktivitas-aktivitas berkualitas yang dilakukan bersama untuk menciptakan perkembangan anak yang lebih baik.

\section{Instrumen penelitian}

Instrumen penelitian menggunakan kuesioner yang telah diuji validitas dan reliabilitasnya dengan hasil pada tabel 1 . Variabel tingkat stres ibu, waktu asuh dan kedekatan ibu anak r hitung $\geq 0.20$, serta Cronbach's

Tabel 1. Hasil uji reliabilitas

\begin{tabular}{llc}
\hline Variabel & Item Total Correlation (r) & Alpha Cronbach \\
\hline Tingkat Stres Ibu & $\geq 0.20$ & 0.83 \\
Waktu Asuh Ibu & $\geq 0.31$ & 0.75 \\
Kedekatan Ibu Anak & $\geq 0.29$ & 0.74 \\
\hline
\end{tabular}

Alpha $\geq 0.70$ sehingga semua butir pertanyaan dinyatakan reliabel.

\section{Analisis Data}

Analisis data menggunakan analisis univariat, analisis bivariat, dan multivariat. Pengaruh variabel independen terhadap variabel dependen dianalisis menggunakan uji Pearson. Analisis multivariat dengan path analysis. Analisis jalur terdiri dari 5 langkah untuk melakukan analisis data, sebagai berikut: spesifikasi model, identifikasi model, kesesuaian model, estimasi parameter, dan respesifikasi model.

\section{HASIL}

Tabel 2 menunjukkan karakteristik subjek penelitian yang meliputi usia ibu, pendidik- an ibu, pekerjaan ibu, pendapatan keluarga, usia anak, usia kehamilan, dan berat badan lahir.

\section{Tabel 2. Karakteristik subjek penelitian}

\begin{tabular}{|c|c|c|}
\hline Karakteristik & $\mathbf{n}$ & $\%$ \\
\hline \multicolumn{3}{|l|}{ Usia Ibu } \\
\hline$\leq 35$ tahun & 84 & 70 \\
\hline$\geq 36$ tahun & 36 & 30 \\
\hline \multicolumn{3}{|l|}{ Pendidikan Ibu } \\
\hline Tidak Sekolah & o & o \\
\hline SD & 14 & 11.7 \\
\hline SMP & 26 & 21.7 \\
\hline SMA & 48 & 40.0 \\
\hline Perguruan tinggi & 32 & 26.7 \\
\hline \multicolumn{3}{|l|}{ Pekerjaan Ibu } \\
\hline Ibu Rumah Tangga & 69 & 57.5 \\
\hline Buruh & 6 & 5 \\
\hline Swasta & 27 & 22.5 \\
\hline Wiraswasta & 16 & 13.3 \\
\hline PNS & 2 & 1.7 \\
\hline \multicolumn{3}{|l|}{ Pendapatan Keluarga } \\
\hline$<\operatorname{Rp} 1,534,985$ & 48 & 40 \\
\hline$\geq \operatorname{Rp} 1,534,985$ & 72 & 60 \\
\hline \multicolumn{3}{|l|}{ Umur Anak } \\
\hline 5 Tahun & 31 & 25.8 \\
\hline 5 Tahun 6 Bulan & 18 & 15 \\
\hline 6 Tahun & 71 & 59.2 \\
\hline \multicolumn{3}{|l|}{ Riwayat Usia Kehamilan } \\
\hline < 37 M̈inggu & 30 & 25 \\
\hline$\geq 37$ Minggu & 90 & 75 \\
\hline \multicolumn{3}{|l|}{ Riwayat Berat Badan Lahir } \\
\hline$<2,500$ gram & 45 & 37.5 \\
\hline$\geq 2,500$ gram & 75 & 62.5 \\
\hline
\end{tabular}


Tabel 3. Analisis univarat variabel penelitian

\begin{tabular}{lccccc}
\hline \multicolumn{1}{c}{ Variabel } & n & Mean & SD & Min. & Maks. \\
\hline Perkembangan & 120 & 8.54 & 1.45 & 5 & 10 \\
Usia kehamilan & 120 & 37.07 & 1.30 & 33 & 41 \\
Berat badan lahir & 120 & $2,832.08$ & 537.53. & 1950 & 4000 \\
Tingkat stres ibu & 120 & 57.20 & 11.37 & 30 & 75 \\
Pendapatan keluarga & 120 & $3,228,750$ & $3,498,219.31$ & 500,000 & 20, ooo,ooo \\
Waktu asuh ibu & 120 & 8.03 & 1.99 & 4 & 10 \\
Kedekatan ibu anak & 120 & 8.33 & 1.58 & 5 & 10 \\
\hline
\end{tabular}

Tabel 4. Distribusi frekuensi variabel penelitian dengan data kategorikal

\begin{tabular}{lccc}
\hline & Variabel & n & \% \\
\hline Pendidikan Ibu & & & 66.7 \\
$\geq$ SMU & 80 & 33.3 & \\
< SMU & 40 & & \\
Pekerjaan Ibu & & & 57.5 \\
Bekerja dalam rumah & 69 & 42.5 \\
Bekerja luar rumah & 51 & \\
\hline
\end{tabular}

Tabel 3 menunjukkan bahwa masingmasing variabel memiliki keberagaman data yang relatif kecil. Mean menggambarkan nilai rata-rata, sedangkan nilai standard deviation (SD) menggambarkan seberapa jauh bervariasinya data. SD yang kecil merupakan indikasi bahwa data representatif.Tabel 4 menunjukkan distribusi frekuensi tentang variabel pendidikan dan pekerjaan ibu dengan data kategorikal. Seba- gian besar ibu berpendidikan $\geq$ SMU sebanyak $66.7 \%$ dan sebagian besar bekerja diluar rumah sebanyak 57.5\%.

Tabel 4 menunjukkan bahwa prematuritas, berat badan lahir, tingkat stres ibu, pendidikan ibu, pekerjaan ibu, pendapatan keluarga, waktu asuh ibu dan kedekatan ibu anak memiliki pengaruh positif terhadap perkembangan anak dan secara statistik signifikan.

Tabel 5. Analisis bivariat pengaruh prematuritas, berat badan lahir, tingkat stres ibu, status sosioekonomi dan kedekatan ibu anak terhadap perkembangan anak.

\begin{tabular}{lcc}
\hline \multicolumn{1}{c}{ Variabel Independen } & $\mathbf{r}$ & $\mathbf{p}$ \\
\hline Usia kehamilan & 0.50 & $<0.001$ \\
Berat badan lahir & 0.46 & $<0.001$ \\
Tingkat stress ibu & -0.17 & 0.051 \\
Pendidikan ibu & 0.52 & $<0.001$ \\
Pekerjaan ibu & 0.37 & $<0.001$ \\
Pendapatan keluarga & 0.39 & $<0.001$ \\
Waktu asuh ibu & 0.43 & $<0.001$ \\
Kedekatan ibu anak & 0.45 & $<0.001$ \\
\hline
\end{tabular}

Gambar 1 menunjukkan model struktural setelah dilakukan estimasi menggunakan IBM SPSS AMOS 20, sehingga didapatkan nilai seperti pada gambar tersebut. Indikator yang menunjukan kesesuaian model analisis jalur yaitu seperti pada Tabel 5 juga menunjukan adanya goodness of fit mea- sure (pengukuran kecocokan model) bahwa didapatkan hasil fit index(indeks kecocokan) CMIN sebesar 0.92 dengan $\mathrm{p}=0.524>$ $0.05 ; \mathrm{NFI}=0.97 \geq 1.00 ; \mathrm{CFI} 1.00 \geq 0.95$; RMSEA $=0.00 \leq 0.08$ yang berarti model empirik tersebut memenuhi kriteria yang 
Journal of Maternal and Child Health (2017), 2(3): 187-199

https://doi.org/10.26911/thejmch.2017.02.03.01

ditentukan dan dinyatakan sesuai dengan data empirik.

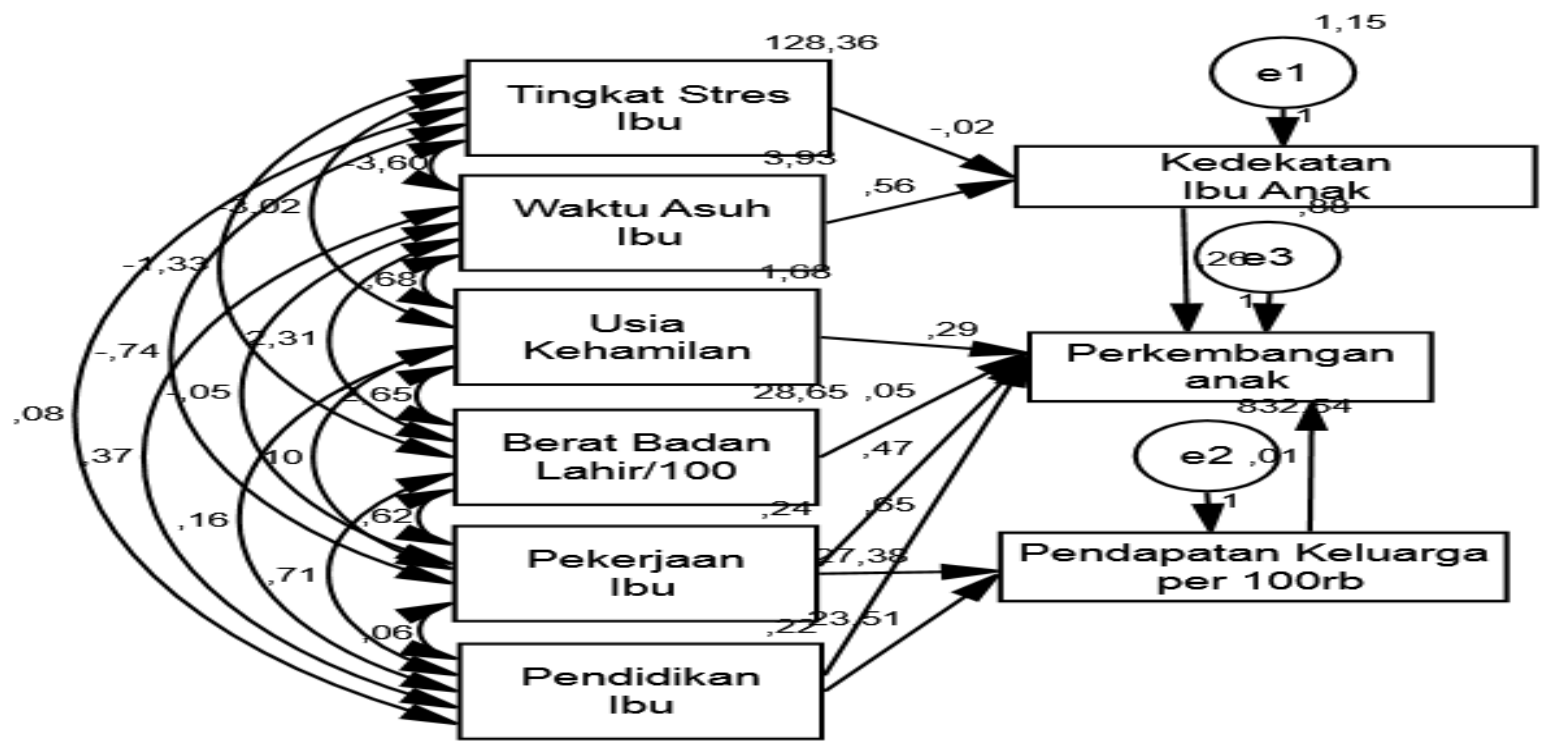

Gambar 1. Model struktural analisis jalur

Tabel 6. Hasil analisis jalur pengaruh prematuritas, berat badan lahir, tingkat stres ibu, status sosioekonomi dan kedekatan ibu anak terhadap perkembangan anak prasekolah

\begin{tabular}{|c|c|c|c|c|c|}
\hline & Variabel Independen & $\mathbf{b}^{*}$ & SE & p & $\boldsymbol{\beta}^{* *}$ \\
\hline & \multicolumn{5}{|c|}{ Pengaruh Langsung } \\
\hline Perkembangan anak prasekolah & $\leftarrow$ Usia kehamilan & 0.29 & 0.07 & $<0.001$ & 0.29 \\
\hline Perkembangan anak prasekolah & $\leftarrow$ Berat badan lahir & 0.04 & 0.18 & 0.007 & 0.18 \\
\hline Perkembangan anak prasekolah & $\leftarrow$ Pekerjaan ibu & 0.46 & 0.20 & 0.020 & 0.16 \\
\hline Perkembangan anak prasekolah & $\leftarrow$ Pendidikan ibu & 0.65 & 0.21 & 0.002 & 0.21 \\
\hline Perkembangan anak prasekolah & $\leftarrow$ Kedekatan ibu anak & 0.26 & 0.05 & $<0.001$ & 0.28 \\
\hline \multirow{2}{*}{$\begin{array}{l}\text { Perkembangan anak prasekolah } \\
\text { Pengaruh Tidak Langsung }\end{array}$} & $\leftarrow$ Pendapatan & 0.01 & 0.01 & 0.015 & 0.17 \\
\hline & \\
\hline Kedekatan ibu anak & $\leftarrow$ Tingkat stres ibu & -0.01 & 0.01 & 0.052 & -0.12 \\
\hline Kedekatan ibu anak & $\leftarrow$ Waktu asuh ibu & 0.56 & 0.05 & $<0.001$ & 0.70 \\
\hline Pendapatan & $\leftarrow$ Pekerjaan ibu & $27 \cdot 37$ & $5 \cdot 5^{2}$ & $<0.001$ & 0.38 \\
\hline Pendapatan & $\leftarrow$ Pendidikan ibu & 23.50 & $5 \cdot 79$ & $<0.001$ & 0.31 \\
\hline \multicolumn{6}{|l|}{ Model Fit } \\
\hline \\
\hline \multicolumn{6}{|c|}{$\begin{array}{lll}\text { CMIN } & =0.92 \quad p=0.524(>0.05) \\
\text { NFI } & =0.97 \quad(\geq 0.90)\end{array}$} \\
\hline \multicolumn{6}{|l|}{ CFI $=1.00 \quad(\geq 0.95)$} \\
\hline \multicolumn{6}{|l|}{ RMSEA $=0.00 \quad(\leq 0.08)$} \\
\hline \multicolumn{4}{|c|}{ *: koefisien jalur tidak terstandarisasi } & & \\
\hline
\end{tabular}

Melalui Tabel 6 dapat diketahui bahwa perkembangan anak prasekolah dipengaruhi secara langsung oleh prematuritas, berat badan lahir, pekerjaan ibu, pendidikan ibu, kedekatan ibu anak dan pendapatan keluarga.

Setiap peningkatan satu unit usia kehamilan akan meningkatkan perkembang- an anak sebesar 0.29 unit $(b=0.29, \mathrm{SE}=$ 0.07, $\mathrm{p}=<0.001$ ).

Setiap peningkatan satu unit berat badan lahir akan meningkatkan perkembangan anak sebesar 0.04 unit $(b=0.04$, $\mathrm{SE}=0.18, \mathrm{p}=0.007)$.

Setiap peningkatan satu unit pekerjaan ibu akan meningkatkan perkembangan 
anak sebesar 0.46 unit $(\mathrm{b}=0.46, \mathrm{SE}=$ $0.20, \mathrm{p}=0.020$ ).

Setiap peningkatan satu unit pendidikan ibu akan meningkatkan perkembangan anak sebesar 0.65 unit $(b=0.65, \mathrm{SE}=$ $0.21, \mathrm{p}=0.002$ ).

Setiap peningkatan satu unit kedekatan ibu anak akan meningkatkan perkembangan anak sebesar 0.26 unit (b = $0.26, \mathrm{SE}=0.05, \mathrm{p}=<0.001$ )

Setiap peningkatan satu unit pendapatan keluarga akan meningkatkan perkembangan anak sebesar 0.00 unit $(\mathrm{b}=$ 0.01, $\mathrm{SE}=0.01, \mathrm{p}=0.015$ ).

Setiap peningkatan satu unit tingkat stres akan menurunkan kedekatan ibu anak sebesar -0.01 unit ( $b=-0.01, \mathrm{SE}=0.01, \mathrm{p}=$ o.052).Setiap peningkatan satu unit waktu asuh ibu akan meningkatkan kedekatan ibu anak sebesar 0.56 unit $(b=0.56, \mathrm{SE}=0.05$, $\mathrm{p}=<0.001)$.

Setiap peningkatan satu unit pekerjaan ibu akan meningkatkan pendapatan sebesar 27.37 unit ( $b=27.37, \mathrm{SE}=5.52$, $\mathrm{p}$ $=<0.001)$. Setiappeningkatan satu unit pendidikan ibu akan meningkatkan pendapatan sebesar 23.50 unit ( $b=23.50, \mathrm{SE}=5.79$, $\mathrm{p}=<0.001)$.

\section{PEMBAHASAN \\ 1. Pengaruh prematuritas terhadap perkembangan anak prasekolah di Kota Surakarta.}

Hasil dari penelitian ini menunjukkan bahwa terdapat pengaruh premarutitas dengan perkembangan anak. Anak yang lahir dengan riwayat prematur akan mengalami gangguan dalam tahap perkembangannya seperti keterlambatan dalam perkembangan kognitif dan bahasa, perkembangan motorik dan visual, gangguan psikososial dan perilaku serta mengalami keterlambatan dalam pencapaian bidang akademik disekolah (de Kieviet et al, 2009).
Penelitian oleh Schepers et al (2012) sejalan dengan hasil penelitian ini. Perkembangan kognitif dan motorik anak prematur mengalami keterlambatan dibanding anak dengan riwayat lahir aterm. Keterlambatan pada perkembangan kognitif pada anak prasekolah dapat juga diketahui melalui nilai IQ dan matematika rendah serta kemampuan verbal yang kurang (Solimani, 2007).

Prematur juga berhubungan erat dengan terjadinya keterlambatan dalam bahasa anak. Bahasa anak mempengaruhi komunikasinya dengan sekitar sehingga berakibat pada menurunnya prestasi akademik dan fungsi sosial. Menurut Reydi et al., (2013), anak prematur lebih lemah dalam bidang bahasa yang meliputi tata bahasa, dialog dan mempresepsikan suatu ucapan dibanding anak aterm seusianya.

Anak prematur akan mengalami masalah sosial emosional seperti rendahnya hubungan sosial dan kurangnya interaksi yang terjalin dengan lingkungan sekitar (Treyvaud et al, 2011).

\section{Pengaruh berat badan lahir ter- hadap perkembangan anak prase- kolah di Kota Surakarta.}

Hasil penelitian ini menunjukkan bahwa terdapat pengaruh antara berat badan lahir dengan perkembangan anak. Berat badan lahir berhubungan erat dengan proses perkembangan pada anak baik pada sekarang, masa anak-anak maupun pada masa dewasa. Anak dengan riwayat berat badan lahir normal akan mengurangi timbulnya masalah kesehatan dikemudian hari, akan tetapi anak dengan riwayat berat badan lahir rendah berisiko tinggi untuk mengalami berbagai masalah kesehatan termasuk menurunnya proses perkembangan dimasa mendatang. Berat badan lahir terutama riwayat lahir rendah, berhubungan dengan terjadinya masalah baik pertumbuhan fisik, perkembangan kognitif, gang- 
Journal of Maternal and Child Health (2017), 2(3): 187-199

https://doi.org/10.26911/thejmch.2017.02.03.01

guan perilaku sosial yang nantinya akan berdampak pada proses belajar anak. Anak dengan riwayat berat badan lahir rendah (BBLR), pencapaian akademik rendah, nilai IQ rendah dan dan akan mengalami gangguan perkembangan motorik. Selain itu, anak juga berisiko mengalami autis akibat dari gangguan neurodevelopmental serta anak juga akan mengalami gangguan dalam perkembangan bahasanya (Losh et al., 2012).

Penelitian ini sejalan dengan penelitian yang dilakukan oleh Rautava et al (2010) yang menunjukkan bahwa berat badan lahir mempengaruhi perkembangan anak pada usia 5 tahun. Anak dengan riwayat BBLR akan mengalami gangguan pada kemampuan motorik, lemahnya pandangan akan sesuatu hal, daya ingat, bahasa, sosial emosional dibanding anak dengan riwayat berat badan lahir normal.

\section{Pengaruh tingkat stres ibu terha- dap perkembangan anak prasekolah di Kota Surakarta.}

Hasil penelitian ini menunjukkan bahwa terdapat pengaruh tidak langsung antara tingkat stres ibu dengan perkembangan anak. Stres yang dialami ibu merupakan salah satu faktor lingkungan yang berperan secara tidak langsung dalam menghambat perkembangan anak. Stres pada ibu berpengaruh terhadap kedekatan yang terjalin antara ibu dan anak. Ibu dengan stres yang tinggi menjadi kurang responsif, lebih otoriter dan lebih lalai dalam mengurus anak. Hal ini menyebabkan pada kedekatan ibu anak menjadi berkurang dan berakibat pada perkembangan anak menjadi menurun (Neece et al, 2012).

Permasalahan seperti penyesuaian lingkungan pada anak terjadi akibat rendahnya kedekatan yang terjalin antara ibu dan anak. Stres pada ibu menyebabkan anak mengalami tekanan emosional sehingga anak lebih tergantung pada orang lain dan lebih besar mengalami gangguan asosiatif. Penelitian ini sejalan dengan penelitian yang dilakukan oleh Choe et al., (2013), yang menyatakan bahwa stres yang dialami ibu berhubungan dengan kehangatan yang diciptakan oleh ibu yang nantinya akan mempengaruhi kedekatan yang terjalin pada ibu dan anak.

Ibu berhubungan dengan keterlambatan perkembangan pada anak. Ibu yang mengalami terbukti kurang dapat diandalkan dalam mengasuh anak dan juga kurang responsif terhadap permasalahan anak. Dua masalah tersebut merupakan dua faktor penting dalam membentuk hubungan dan terjalinnya kedekatan antara ibu dan anak. Ibu memegang peranan utama dalam menciptakan sebuah hubungan yang sehat dengan anak. Sehingga ibu dituntut untuk memiliki kesehatan baik secara fisik maupun mentalHuang et al (2014).

\section{Pengaruh pekerjaan ibu terhadap perkembangan anak prasekolah di Kota Surakarta.}

Hasil penelitian ini menunjukkan bahwa terdapat pengaruh pekerjaan ibu dengan perkembangan anak. Hasil penelitian tersebut berbeda dengan penelitian yang dilakukan oleh Almani et al., (2012), yang menunjukkan bahwa tidak ada perbedaan yang signifikan pada perkembangan anak diantara ibu yang bekerja di luar rumah dengan ibu yang bekerja didalam rumah.

Penelitian yang dilakukan oleh Lombardi dan Coley (2014), terdapat perbedaan yang tidak berarti dan secara statistik tidak signifikan antara pekerjaan ibu terhadap kemampuan membaca yang kurang pada anak di lingkungan taman kanak-kanak.

Ibu yang bekerja kemungkinan kecil mengalami tekanan baik secara fisik dan psikis dari suami dan tekanan psikis dari anak dibanding dengan ibu yang bekerja dirumah ibu yang bekerja dirumah. Ibu yang tidak bekerja kemungkinan akan me- 
rasa bosan berada dilingkungan rumah dengan segala aktifitas yang sama setiap harinya, hal ini mungkin berbanding terbalik dengan ibu yang bekerja serta memiliki lingkungan yang berbeda yaitu dirumah maupun dilingkungan tempat kerja. Ibu yang bekerja juga akan memilih tempat kerja yang dirasa nyaman baginya. Seorang ibu yang bekerja memiliki kebanggaan tersendiri pada dirinya bahwa iatelah menjadi individu yang mandiri dan produktif. Ibu yang bekerja akan memberikan contoh yang baik bagi anaknya untuk bertanggungjawab dalam setiap pekerjaan yang dilakukan. Keadaan yang dialami oleh ibu tersebut akan mempengaruhi emosional ibu dalam mendidik mengajar dan menuntun anaknya sehingga akan berdampak pada perkembangan anak menjadi lebih baik.

Ibu yang bekerja diluar rumah akan menambah penghasilan keluarga yang digunakan untuk menyediakan lingkungan dan alat permainan untuk anak, menyekolahkan disekolah favorit, menyediakan makanan yang cukup serta mencarikan pengasuh yang berkompeten, sehingga perkembangan anak akan menjadi lebih baik walaupun ibu bekerja.

\section{Pengaruh pendapatan terhadap perkembangan anak prasekolah di Kota Surakarta.}

Hasil penelitian ini menunjukkan bahwa terdapat pengaruh pendapatan dengan perkembangan anak. Penelitian ini sejalan dengan penelitian yang dilakukan oleh Martin et al., (2010) yang menyatakan bahwa pendapatan dari orangtua berpengaruh besar terhadap perkembangan anak. Pendapatan orangtua yang tinggi memungkinkan mereka untuk memenuhi segala kebutuhan anak dalam periode perkembangannya. Pendapatan orangtua secara otomatis meningkatkan status sosial lebih tinggi. Orangtua dengan mudah mendapatkan lingkungan rumah yang layak, sekolah yang bagus, kebutuhan nutrisi yang seimbang serta menyediakan lingkungan bermain dan fasilitas permainan yang menstimulasi perkembangan anak.

Penelitian ini sejalan dengan penelitian yang dilakukan oleh Rowe (2008) tentang hubungan status sosioekonomi terhadap kemampuan perbendaharaan kata. Orangtua dengan pendapatan dan pendidikan yang tinggi lebih banyak menguasai kata-kata dan kalimat dalam berkomunikasi denga anak, sehingga anak lebih menjadi kaya dalam mengingat dan mengungkapkan perbendaharaan kata.

Anak dilahirkan dan tumbuh dalam lingkungan yang serba kekurangan akibat dari pengasilan atau pendapatan orangtua yang rendah akan mengalami banyak kerugian dalam mencapai proses kehidupan yang layak. Hal ini terjadi karena anak yang tumbuh dilingkungan tersebut memiliki keadaan rumah dan lingkungan buruk. Anak akan sangat rentan mengalami berbagai tindakan kriminal, pelecahan, berbagai penyakit terutama penyakit menular. Keadaan tersebut berpengaruh terhadap perkembangan kognitif yang nantinya berdampak pada pencapaian prestasi pada anak di sekolah (Dahl dan Lochner, 2012).

\section{Pengaruh pendidikan ibu terhadap perkembangan anak prasekolah di Kota Surakarta.}

Hasil penelitian ini menunjukkan bahwa terdapat pengaruh pendidikan ibu dengan perkembangan anak. Penelitian ini sejalan dengan penelitian yang dilakukan oleh Schady (2011), yang membuktikan bahwa pendidikan orangtua terutama ibu mempunyai hubungan yang kuat dengan perkembangan anak. Pendidikan ibu tinggi akan menjadikan pendapatan keluarga semakin tinggi serta perkembangan anak semakin baik. Perkembangan anak yang lebih rendah pada ibu dengan pendidikan yang rendah terjadi karena anak kurang menda- 
Journal of Maternal and Child Health (2017), 2(3): 187-199

https://doi.org/10.26911/thejmch.2017.02.03.01

patkan sarana prasarana yang mendukung perkembangan anak, seperti akses ke pendidikan prasekolah yang baik, keadaan rumah yang tidak layak dan tidak terpenuhi kebutuhan makanan yang seimbang.

Penelitian yang dilakukan Wade et al., (2014), membuktikan bahwa pendidikan yang dicapai ibu selama hidupnya mempunyai hubungan yang erat dengan pencapaian anak-anak dalam perkembangan bahasa dilingkungan sosial terutama dilingkungan sekolah anak.

\section{Pengaruh waktu asuh ibu terhadap perkembangan anak prasekolah di Kota Surakarta.}

Hasil penelitian ini menunjukkan bahwa terdapat pengaruhwaktu asuh ibu dengan perkembangan anak melalui kedekatan ibu anak. Anak pada usia prasekolah, waktu yang dihabiskan bersama ibu selama satu jam akan lebih memberikan manfaat pada perkembangannya dibanding dengan waktu yang dihabiskan sendiri untuk belajar disekolah. Selama usia tersebut pula, komunikasi dan perhatian yang diberikan ibu akan memberikan pengaru besar bagi anak. Kegiatan bersama yang dilakukan seperti membacabuku,bermain teka-teki dan mencoba keterampilan memecahkan masalah bersama akan merangsang perkembangan kognitif anak. Sehingga pada akhirnya anak di sekolah dapat dengan mudah mengenali huruf dan angka serta mengindentifikasi kata-kata (Snow, 2006).

Semakin banyak waktu yang dihabiskan orangtua untuk memantau dan menemani anak maka hubungan yang terjalin antara ibu dan anak semakin dekat. Orangtua terutama ibu yang lebih banyak menghabiskan waktu untuk memantau aktivitas anak seperti kegiatan akademis dan pencapaian, hubungan sosial anak dengan lingkungan serta pribadi anak itu sendiri akan berpengaruh pada terciptanya hubungan yang lebih intim antara ibu dan anak yang pada akhirnya orangtua akan memastikan anak memiliki perkembangan yang baik. Peningkatan nilai IQ pada anak berhubungan dengan keterlibatan orangtua dalam mendidik anak. Orangtua yang lebih banyak menghabiskan waktu dengan anak akan mempengaruhi pencapaian perkembangan kognitif anak di sekolah seperti membaca, menulis dan menghitung (Topor et al., 2010).

Waktu yang lebih banyak ibu luangkan dalam merawat anak, mendampingi, membimbing serta mengelola emosional anak berhubungan dengan perkembangan anak yang lebih baik. Hal ini terjadi karena ibu lebih menunjukkan ekspresi yang mendalam dalam merespon setiap reaksi yang ditunjukkan anak dibanding dengan reaksi yang diberikan ayah (Han dan Jun, 2013).

\section{Pengaruh kedekatan ibu anak ter-} hadap perkembangan anak prasekolah di Kota Surakarta.

Hasil penelitian ini menunjukkan bahwa terdapat pengaruh kedekatan ibu anak dengan perkembangan anak. Perlakuan orangtua terutama ibu yang bersifat negatif seperti tindakan yang kasar, tidak konsisten menciptakan hubungan yang baik akan berpengaruh negatif pada perkembangan anak. Sebaliknya ibu dengan perilaku yang positif seperti menciptakan suasana yang menyenangkan, sikap yang hangat dan terbuka akan berpengaruh positif terhadap perkembangan anak. Kedekatan ibu anak ini pada akhirnya akan mempengaruhi pencapaian akademik anak diusia sekolah (Stack et al., 2012).

Penelitian ini sejalan dengan penelitian yang dilakukan oleh Dubois-Comtois et al., (2013), dimana kualitas kedekatan antara ibu dan anak terjalin melalui interaksi yang intim merupakan faktor yang mempengaruhi bagaimana anak berperilaku dimasanya. Usia 6 sampai 12 tahun merupakan masa dimana anak beradatasi 
dengan lingkungan sosial yang lebih luas, sehingga perhatian dan kepedulian orangtua berpengaruh besar dalam menuntun anak bersosialisasi dengan baik.

Penelitian yang dilakukan oleh DeKlyen dan Greenberg (2008) menunjukkan bahwa perkembangan perilaku pada anak dipengaruhi oleh berbaga faktor seperti lingkungan keluarga dan fungsi psikososial ibu serta dipengaruhi oleh kualitas kedekatan yang terbentuk antara ibu dan anak. Tingkat sensitivitas ibu terhadap anaknya berpengaruh besar dalam perkembangan internal anak di masa prasekolah. Ibu dengan dukungan yang penuh, memberikan respon yang cepat serta umpan balik yang positif pada anaknya akan meningkatkan kedekatan ibu anak. Peningkatan kedekatan ibu anak ini mempengaruhi reaksi emosional anak menjadi lebih baik. Tetapi, bila tingkat sensitivitas ibu berkurang makan anak akan mudah cemas dan depresi menjadi penyendiri dan menimbulkan reaksi emosional yang buruk (Kok et al., 2013).

\section{REFERENCE}

Almani AS, Abro A, Mugher RA(2012). Study of the Effects of Working Mothers on the Development of Children in Pakistan.InternationalJournal of $\mathrm{Hu}-$ manities and Social Science 2(11):164171.

Chen Y, Li H (2009). Mother's education and child health: Is there a nurturing effect?. Journal of Health Economics 28: 413-426.

Choe DE, Olson SL, Sameroff AJ(2013). Effects of early maternal distress and parenting on the development of children'sself-regulation and externalizing behavior. Development and Psychopathology 25:437-453.
Cooper PJ, Tomlinson M, Swartz L, Landman M, Molteno C, Stein A, McPherson $K$ (2009). Improving quality of mother-infant relationship and infant attachment in socioeconomically deprived community in South Africa: randomised controlled trial BMJ 1-8.

Dahl GB, Lochner L (2012). The Impact of Family Income on Child Achievement: Evidence from the Earned Income Tax Credit. American Economic Review 102(5): 1927-1956.

Daniel B, Wassell S, Gilligan R(2010). Child Development for Child Care and Protection Workers (2nd edition). London: Jessica Kingsley Publishers.

DeKlyen M, Greenberg MT (2008). Attachment and psychopathology in childhood. New York: Guilford Press.

Dubois-Comtois K, Moss M, Cyr C, Pascuzzo K (2013). Behavior Problems in MiddleChildhood: The Predictive Role of Maternal Distress, Child Attachment, and Mother-Child Interactions. J Abnorm Child Psychol. 41:13111324 .

Estes A, Munson J, Dawson G, Koehler E, Zhou XH, Abbott R(2009). Parenting stress and psychological functioning among mothers of preschool children with autism and developmental delay. Autism. 13(4): 375-387.

Gill S, Nix RL, Bierman KL, Domitrovich CE (2013). Promoting Children's SocialEmotional Skills in Preschool Can Enchance Academic Behavioral Functioning in Kindergarten. Early Education \& Development 24(7): 10001019.

Han SY, Jun PW (2013).Parental Involvement in Child's Development: Father vs. Mother. Open Journal of Medical Psychology 2:1-6. 
Journal of Maternal and Child Health (2017), 2(3): 187-199

https://doi.org/10.26911/thejmch.2017.02.03.01

Hidayat AA (2008). Pengantar Ilmu Kesehatan Anak. Jakarta: Salemba Medika.

Hsin A, Felfe C (2014). When Does Time Matter? Maternal Employment, Children's Time With Parents, and Child Development. Demography, 51:18671894.

Huang CY, Conteines J, Ayala C, Kaufman JS (2014). Parenting Stress, Social Support, and Depression for Ethnic Minority Adolescent Mothers: Impact on Child Development. J Child Fam Stud 23(2): 255-262.

Joyce C, Goodman BM, Hardin A(2012). Preterm Birth and Low Birth Weight. The Urban Child Institute 1-10.

Kementrian Kesehatan Republik Indonesia (2014). Peraturan Menteri Kesehatan Republik Indonesia Nomor 66 Tahun 2014 tentang Pemantauan Pertumbuhan, Perkembangan dan Gangguan Tumbuh Kembang Anak. http://depkes.go.id. Di akses 12 Januari 2017.

Kim H, Munson MR, McKay MM (2012). Engagement in Mental Health Treatment Among Adolescents and Young Adults: A Systematic Review. Child and Adolescent Social Work Journal. 29(3): 241-266.

Kok R, Linting M, Bakermans-Kranenburg MJ, Van-Ijzendoorn MH, Jaddoe VW, HofmanA,Verhulst FC (2013). MaternalSensitivity and Internalizing Problems: Evidence from Two Longitudinal Studies in Early Childhood. ChildPsychiatryHuman Development 44:751765

Lombardi MC, Coley LR (2014). Early Maternal Employment and Children's School Readiness in Contemporary Families. Developmental Psychology 50(8):2071-2084.

Losh M, Esserman D, Anckarsater H, Sullivan PF, Lichtenstein P (2012). Lower

birth weight indicates higher risk of autistic traits in discordant twin pairs. PsychologicalMedicine42:1091-1102.

Martin MJ, Conger RD, Schofield TJ, Dogan SJ, Widaman KF, Donnellan MB, Neppl TK(2010). Evaluation of the interactionist model of socioeconomic status and problem behavior: A developmental cascade across generations. Development and Psychopathology. 22: 695-713.

Neece LC, Greeb SA, Baker BL (2012). Parenting Stress and Child Behavior Problems: A Transactional Relationship Across Time. American Journal on intellectual and Developmental Disabilities 117(1): 48-66.

Negrato CA,Gomes MB(2013). Low Birth Weight: Causes and Consequences. Diabetology \& Metabolic Syndrome. 5: 49 .

Noordiati, Hakimi M, Wibowo T (2011). Hubungan Kepekaan Serta Ketanggapan Pengasuhan Ibu Terhadap Perkembangan Anak Prasekolah. Jurnal Kedokteran Masyarakat 27(1) : 18-23.

Rautava L, Anderson S, Gissler M, Hallman M, Hakkinen U, Korvenranta E, Leipala J (2010). Development and behaviour of 5-year-old very low birthweight infants. Eurpoan Child Adolescen Psychiatry 19:669-677.

Rowe L, Meredith (2008). Child-directed speech: relation to socioeconomicstatus, knowledge of child development and child vocabulary skill. Journal Child Languange 35: 185-205.

Schady N (2011). Parents Education, Mother Vocabulary and Cognitive Development in Early Childhood: Longitudinal Evidence From Ecuador. American Journal of Public Health 101(12): 2299-2307.

Schepers S, Dekovic M, Feltzer M, de Kleine M, van Baar A (2012). Drawings of 
very preterm-born children at 5 years of age: a first impression of cognitive and motor development?. Europan Journal Pediatric 171:43-50.

Solimani F (2007). Developmental Outcome of Low-Birth-Weight Premature Infan. Iran Journal Pediatric, 17(1): 117-125.

Spittle AJ, Barton S, Treyvaud K, Molloy CS, Doyle LW, Anderson PJ (2016). SchoolAge Outcomes of Early Intervention for Preterm Infants and Their Parents: A Randomized Trial. Pediatrics. 138: e2 0161363.

Stack MD, Serbin LA, Girouard N, Enns LN, Bentley VM, Ledingham JE, Schwartzman AE(2012). The quality of the mother-child relationship in high-risk dyads: Application of the Emotional Availability Scales in an intergenerational, longitudinal study.
Development and Psychopathology 24: 93-105.

Topor DR, Keane SP, Shelton TL, Calkins SD (2010). Parent involvement and student academic performance: A multiple mediational analysis. J Prev Interv Community, 38(3): 183-197.

Treyvaud K, Doyle LW, Lee KJ, Roberts G, Lim J, Inder TE, Anderson PJ (2011). Social-Emotional Difficulties in Very Preterm and Term 2 Year Olds Predict SpecificSocial-EmotionalProblems at the Age of 5 Years. Journal of Pediatric Psychology 37(7):779-785.

Wade M, Browne DT, Madigan S, Plamondon A, Jenkins JM (2014). Normal Birth Weight Variation and Children'sNeuropsychological Functioning: Links between Language, Executive Functioning, and Theory of Mind. Journal of the International Neuropsychological Society 20:909-919. 